\title{
BUDIDAYA PADI YANG DIPANGKAS SECARA PERIODIC DAN DIBERI PUPUK KOMPOS Chromolaena odorata DAN ANALISIS USAHATANINYA
}

\author{
Jamilah \\ Fakultas Pertanian Universitas Tamansiswa Padang. Jl. Tamansiswa No. 9 Padang 25138 \\ Email: jamilahfatika@gmail.com
}

\begin{abstract}
The study titled " Rice Cultivation pruned periodically And Fertilized By Chromolaena odorata Compost $(C C)$ " had been carried out during the second period of the growing season, the first season (MT1), and the second season (MT2), was ratoon. The aimed was to reach maximum forage and yield of rice pruned periodically fertilized by C.odorata compost. The experiments were conducted in Split-plot, which was arranged in a completely randomized design. The main plot consists of two levels; not pruned (P0) and pruned (P1). The subplot was three doses of CC, namely; $5 \mathrm{Mg} \mathrm{ha}^{-1}$ (B1); $7.5 \mathrm{Mg} \mathrm{ha}^{-1}$ (B2) and $10 \mathrm{Mg} \mathrm{ha}$ ${ }^{1}$ (B3). The parameters observed; plant height, maximum and productive tiller, the production of forage, the percentage of empty grain, grain weight. Data were analyzed statistically if the real effect of treatment then continued with Honestly Significant Difference test $\alpha 5 \%$. The results proved that there was no influence C.odorata compost, on the growth and yield of rice both at the MT1 and MT2. Forage fodder (HMT) decreased acquisition on MT2 (ratoon) up to 50\% compared to HMT at MT1. An increase in the empty grain to 4-fold in ratoon model (MT2) than MT1. From an economic perspective, there was a loss of farmers, pruning, until MT2, Rp. 2.9 million compared to plants that were not pruned but also be ratoon.
\end{abstract}

Keywords: rice, ratoon, compost Chromolaena odorata, cropping, farming analysis

\begin{abstract}
ABSTRAK
Penelitian dengan judul" budidaya padi yang dipangkas secara periodic dan diberi pupuk kompos Chromolaena odorata" telah dilakukan selama 2 periode musim tanam, yaitu musim tanam 1 (MT1) dan musim tanam 2 (MT2), adalah ratun. Tujuan penelitian untuk mendapatkan hasil pangkasan dan produksi yang maksimal dari tanaman padi yang diberi kompos C.odorata. Percobaan telah dilakukan Kota Padang mulai Bulan November 2014 hingga Juni 2015, dalam bentuk Split plot design, yang disusun dalam Rancangan Lingkungan Acak Lengkap. Petak Utama adalah perlakuan pemangkasan, baik pada MT1 maupun MT2, terdiri atas 2 taraf, yaitu; tidak (P0) dan dipangkas (P1). Anak Petak adalah tiga takaran kompos C.odorata, yaitu; $5 \mathrm{Mg} \mathrm{ha}^{-1}$ (B1); 7,5 $\mathrm{Mg} \mathrm{ha}^{-1} \mathrm{KC}$ (B2) dan $10 \mathrm{Mg} \mathrm{ha}{ }^{-1} \mathrm{KC}$ (B3). Data dianalisis secara statistic, jika perlakuan berpengaruh nyata maka dilanjutkan dengan uji Beda Nyata Jujur a 5\%. Hasil percobaan membuktikan bahwa tidak ada pengaruh yang berbeda antar takaran kompos C.odorata, terhadap pertumbuhan dan hasil padi. Hijauan makanan ternak (HMT) menurun perolehannya pada MT2 hingga 50\%. Terjadi peningkatan gabah hampa hingga 4 kali lipat pada sistem ratun (MT2). Dari segi ekonomi, ada kerugian petani, melakukan pemangkasan, hingga MT2, sebesar Rp. 2,9 juta rupiah dibandingkan tanaman yang tidak dipangkas akan tetapi juga diratunkan.
\end{abstract}

Kata kunci: padi, ratun, kompos Chromolaena odorata, pangkas, analisis usahatani 


\section{PENDAHULUAN}

Tanaman padi satu family dengan tanaman rerumputan, yaitu Gramineae, yang memiliki sifat dan karakter yang tidak jauh berbeda dengan tanaman rumput. Tanaman rumput sudah lama dibudidayakan petani, yang berguna untuk dijadikan Hijauan Makanan Ternak. Pengadaan rumput akhirakhir ini juga menjadi terkendala, akibat lahan untuk budidaya rumput mulai

Deputi Bidang Statistik Distribusi dan Jasa Badan Pusat Statistik, Sasmito Hadi Wibowo mencatat, Indonesia mengalami defisit perdagangan dengan Australia di Agustus 2016 sebesar US \$ 211,3 juta dan US \$1,14 miliar di periode sepanjang Januari-Agustus ini. "Itu karena nilai impor sapi Indonesia dari Australia mencapai US\$ 2,95 miliar di delapan bulan pertama ini. Lebih tinggi dari ekspor kita sebesar US\$1,81 miliar," jelasnya di Kantor BPS, Sasmito menyebut , Indonesia paling banyak mengimpor dari Australia, berupa gandum-ganduman US \$ 620 juta, binatang hidup terutama sapi US \$ 379,9 juta, daging hewan atau daging sapi US \$ 217 juta. "Jadi

Pemanfaatan tanaman padi yang menjadi fungsi ganda, masih terbatas penelitiannya. Beberapa pengalaman petani telah membuktikan bahwa tanaman padi ternyata dapat dipangkas secara periodic, namun belum diketahui mekanisme pemulihan tersebut. Pemangkasan HMT saat memasuki awal primordial bunga sangat tinggi kualitas gizinya. (Jamilah \& Juniarti, 2015) melaporkan bahwa kandungan gizi HMT asal tanaman padi tidak kalah Oleh sebab itu pada penelitian ini ingin membuktikan dan melihat fenomena yang terjadi pada tanaman padi yang secara periodic dipangkas, baik untuk dijadikan HMT maupun melihat kemapuan tanam berkurang. Banyak alih fungsi lahan kering dijadikan perumahan dan pabrik sehingga ini juga menjadi alasan mengapa rumput menjadi terbatas pengadaannya. Alangkah tidak herannya Indonesia terus saja mengimport daging sapi. Petani menjadi enggan memelihara sapi, karena pengadaan Hijauan Makanan Ternak sangat terbatas.

total pasokan Australia ke Indonesia untuk binatang hidup sapi maupun dagingnya mencapai US\$ 596,9 juta dari JanuariAgustus ini," terangnya. Jika dihitung dalam rupiah, angka US \$ 596,9 juta setara dengan Rp 7,88 triliun (kurs 13.200 per dolar AS) sepanjang delapan bulan ini untuk impor daging sapi maupun sapi hidup. Berdasarkan data BPS, Indonesia sudah mengimpor daging sapi dari Australia di Agustus ini senilai US\$ 32,39 juta dengar berat 8,09 juta $\mathrm{Kg}$ daging. Realisasi tersebut naik signifikan dibanding Juli lalu yang seberat 6,06 juta $\mathrm{Kg}$ dengan nilai US\$ 23,01 juta (Liputan 6, 2016).

dibandingkan dengan rumput gajah dan raja. Ternyata tanaman padi dapat dipangkas saat 45 hst tanpa menurunkan hasil gabah kering secara signifikan (Jamilah \& Helmawati, 2015), dan dapat menyediakan HMT yang memadai. Jika petani sebagai peternak, arif, dengan melakukan pemangkasan berseling di lahan sawahnya untuk mendapatkan pakan HMT maka, kesulitan pengadaan HMT pada ternak menjadi teratasi.

tersebut sebagai penghasil gabah. Percobaan ini dilakukan selama 2 musim tanam, dengan musim tanam 1, dipanen HMT saat awal primordial bunga, kemudian tanaman tersebut ditunggu hingga panen, kemudian 
tanaman tersebut diratunkan untuk mendapatkan bibit baru bagi fase pertumbuhan tanaman padi pada musim 2 . Tanaman padi pada musim 2 ini juga dipangkas untuk diambil HMTnya, kemudian dipelihara hingga tanaman memasuki fase matang fisiologis dalam menghasilkan gabah. Oleh sebab itu selama pemeliharaan tanaman tersebut perlu diberi pupuk yang cukup, baik dari pupuk buatan maupun dari kompos Chromolaena odorata.

Pemupukan selain mengadakan unsure hara yang dibutuhkan oleh tanaman, juga bermanfaat sebagai penyedia nutrisi bagi HMT yang dipanen saat sebelum memasuki primordial bunga. Ini salah satu alas an mengapa kandungan nutrisi HMT asal tanaman padi cukup tinggi, karena selalu tanaman padi diberi pupuk yang cukup. Bahkan beberapa kasus, petani memberikan pupuk yang berlebihan di sawah, tanpa

Pada penelitian ini akan membuktikan fenomena kondisi pertumbuhan, HMT dan hasil gabah tanaman padi yang dipangkas secara periodic yang diberi pupuk kompos C.odorata dan buatan, serta mengkaji efek residu kompos C.odorata pada tanaman padi

\section{METODOLOGI}

Percobaan dilakukan pada lahan sawah di Lubuk Minturun dengan ketinggian tempat $22 \mathrm{~m}$ dpl. Percobaan dilakukan hingga 2 musim tanam padi, yaitu musim tanam 1 mulai November 2014 hingga Februari 2015, musim tanam 2 mulai Februari 2015 hingga Mei 2015, ratun padi tanam 1. Percobaan menggunakan benih padi Pandan Wangi, pupuk kompos C.odorata dan pupuk buatan. Percobaan disusun dalam Rancangan Acak Lengkap dengan design Split plot sebagai rancangan perlakuan. Sebagai petak Utama adalah pemangkasan yang terdiri atas 2 taraf, yaitu;
Pemanfaatan kompos C.odorata sudah dibuktikan oleh (Jamilah, Adrinal, Khatib, \& Nusyirwan, 2011); (Jamilah, Juniarti, \& Mulyani, 2016); (Jamilah, Novia, Suardi, \& Renor, 2010); (Jamilah, 2010); (Jamilah, 2011), mampu meningkatkan hasil jagung pada lahan marginal, dan hasil padi pada lahan yang terkena dampak limbah tambang semen, serta lahan sawah Ultisol di Sungai Lareh, Kota Padang.

mendapat peningkatan hasil gabah. Hal ini dianggap tanaman padi sudah sampai jenuh untuk menyerap hara yang diluar kebutuhannya. Oleh sebab itu pemangkasan HMT merupakan alternative yang baik untuk memacu tanaman padi agar meningkatkan kemampuannya menyerap hara yang lebih tinggi dibandingkan tanaman yang tidak dipangkas.

fase ratun (MT2). Tujuan percobaan adalah membuktikan analisis usahatani dan kemampuan tanaman padi Pandan Wangi yang dipangkas secara periodic dalam menyediakan HMT dan Gabah kering giling hingga 2 musim tanam yang dibudidayakan dalam bentuk ratun.

P0. Tidak dipangkas dan P1. Dipangkas saat memasuki primordial bunga. Anak petak terdiri atas 3 jenis kombinasi pupuk yaitu; F1. $5 \mathrm{Mg} \mathrm{ha}{ }^{-1}$ kompos C.odorata (KC) + $100 \%$ pupuk buatan takaran rekomendasi (BPTR) ; F2. 7,5 $\mathrm{Mg} \mathrm{ha}^{-1} \mathrm{KC}+75 \%$ PBTR dan F3. $10 \mathrm{Mg} \mathrm{ha}^{-1} \mathrm{KC}+50 \%$ PBTR. Pupuk buatan rekomendasi sebagai berikut; $100 \mathrm{~kg}$ $\mathrm{ha}^{-1}$ Urea+ $50 \mathrm{~kg} \mathrm{ha}^{-1} \mathrm{ZA}+150 \mathrm{~kg} \mathrm{ha}^{-1}$ SP36 + $100 \mathrm{~kg} \mathrm{ha}^{-1} \mathrm{KCl}$. Jumlah keseluruhan plot sebanyak 18 buah, dengan ukuran $2 \times 2 \mathrm{~m}$, dengan jarak tanam $25 \times 25$ $\mathrm{cm}$. Pada MT1, benih yang telah disemai selama 3 mss, dipindahkan tanamkan 
sebanyak 2 anakan per titik tanam, pada saat memasuki primordial bunga atau 4 hst, dilakukan pemangkasan HMT setinggi 15

Setelah panen padi pada MT1, maka tanaman dibiarkan tumbuh dengan memasukan air irigasi ke semua petakan sawah. Setelah 1 minggu bera, maka dilakukan pemangkasan ratun untuk mempersiapkan bibit padi ratun. Kegiatan ini dilakukan dengan memangkas pendek semua tunggul padi pada $5 \mathrm{~cm}$ dari permukaan tanah (dpt) secara seragam. Air genangan ditinggikan sesuai tingkat umur padi dan tidak menenggelamkan bibit yang

Parameter pengamatan antara lain; tinggi tanaman, anakan maksimum, anakan produktif, berat HMT dan jerami, umur berbunga, panen, panjang malai, jumlah gabah per malai, gabah hampa (\%) dan hasil

\section{HASIL DAN PEMBAHASAN}

Hasil percobaan terhadap 2 musim tanam yang dilakukan, mulai dari musim tanam 1 , hingga musim tanam 2 , tanaman cm dari permukaan tanah (dpt), lalu ditimbang.

tumbuh. Perlakuan pemangkasan untuk panen Hijauan Makanan Ternak (HMT) dilakukan saat memasuki primordial bunga yaitu $30 \mathrm{hsp}$, setinggi $10 \mathrm{~cm}$ dpt. Tanaman padi baik pada MT1 maupun MT2 ratun dipelihara hingga mencapai usia panen, dengan diberi hanya $50 \%$ pupuk buatan takaran rekomendasi sebagai pupuk dasar. Pada MT2 juga diharapkan dapat melihat pengaruh efek residu dari kompos C.odorata yang telah diberikan pada MT1.

gabah kering panen per hektar. Data dianalisis secara statistika, jika perlakuan berpengaruh nyata, maka dilakukan uji lanjut dengan menggunakan HSD taraf nyata $5 \%$.

padi Pandan Wangi yang ditanam di Dataran Rendah (22 m dpl) disajikan sebagai berikut;

\section{Tinggi Tanaman dan jumlah anakan maksimum dan produktif per rumpun tanaman padi}

Pengaruh kombinasi pupuk kompos C.odorata dan pupuk buatan serta efek residu kompos pada musim tanam 2 (ratun) terhadap tinggi tanaman, jumlah anakan maksimum dan anakan produktif disajikan pada Gambar 1.

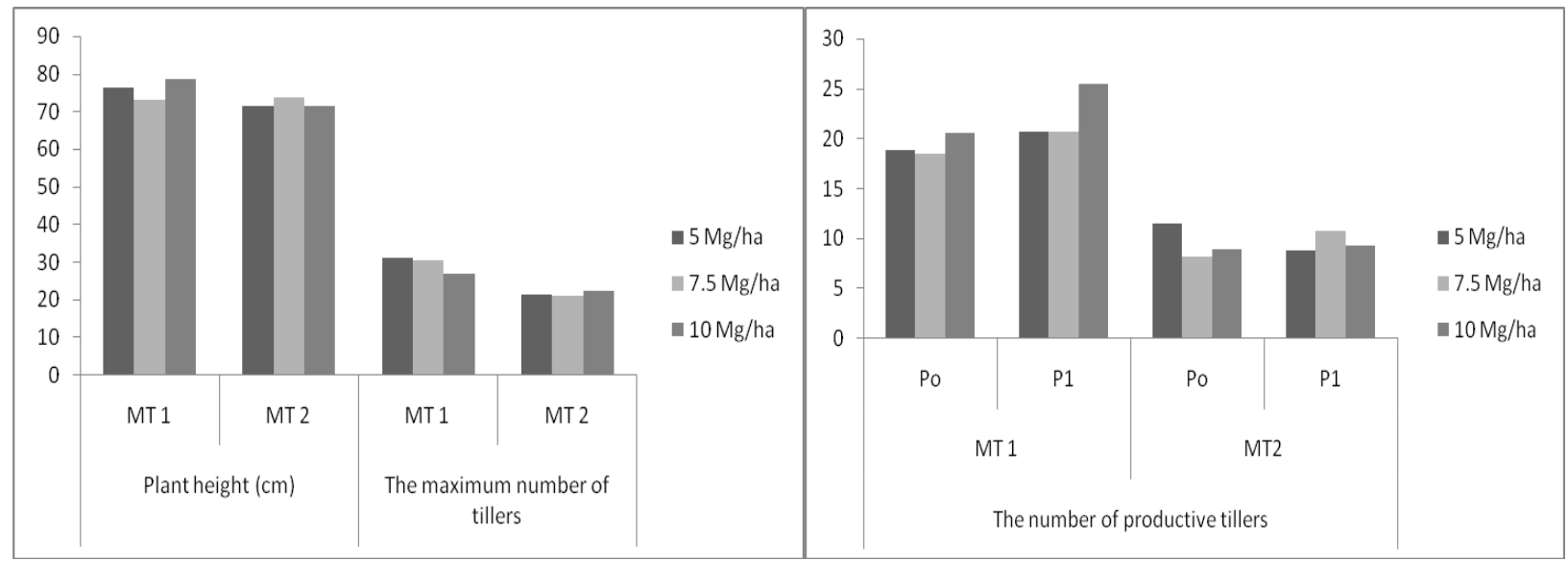

Gambar 1. Pengaruh Kompos C.odorata dan pemangkasan secara periodic terhadap tinggi tanaman, jumlah anakan maksimum dan anakan produktif

Keterangan: MT1, the first planting season; MT 2 ratoon cultivation 
Tidak ada pengaruh kompos terhadap tinggi tanaman, anakan maksimum dan produktif pada musim tanam 1 dan efek residu kompos terhadap tinggi tanaman, anakan maksimum dan produktif padi ratun. Hal ini disebabkan karena tanaman sudah mendapat kebutuhan hara N, P dan $\mathrm{K}$ sesuai dengan yang diharapkan. Walaupun pupuk kompos diberikan sebanyak $5 \mathrm{Mg} \mathrm{ha}{ }^{-1}$ kompos C.odorata, tetap diiringi dengan pupuk buatan $100 \%$, demikian juga semakin tinggi takaran kompos yang diberikan maka takaran pupuk buatan semakin rendah. oleh sebab itu hal ini membuktikan bahwa tanaman bisa mengambil kebutuhan haranya walau tidak seutuhnya berasal dari pupuk buatan saja. Kompos C.odorata yang diberikan selain mengandung unsur hara Anakan maksimum dan anakan produktif padi ratun (MT2) lebih rendah dibandingkan padi MT 1. Tidak ada pengaruh pemangkasan terhadap jumlah anakan produktif baik pada MT1 maupun pada MT 2 (ratun). Terjadi penurunan pembentukan anakan maksimum pada MT2 (ratun), disebabkan ada kecenderungan matinya beberapa anakan yang akan berkembang pada tanah yang ditinggalkan sisa tunggul batang padi saat MT1. Sisa tunggul batang tanaman padi yang tidak makro dan mikro, juga meningkatkan ketersediaan hara di dalam tanah melalui pertukaran pada koloid organiknya, melalui mekanisme pertukaran kation. Semakin banyak humus di dalam tanah, maka KTK tanah semakin meningkat. Di samping unsur hara tidak mudah tercuci, kelarutan unsur hara juga meningkat dan tersedia untuk tanah karena melalui mekanisme pertukaran katian tersebut. Hal ini telah dijelaskan oleh (Dr. Kim H. Tan, 2013); (Larney, Henry Janzen, \& Olson, 2011); (Maswar \& Soelaeman, 2016); (Mengel, Kirkby, Kosegarten, \& Appel, 2001) kompos yang diberikan ke tanah dapat bertahan dalam jangka waktu yang lama hingga musim tanam ke 10.

berkembang menjadi tempat berkembangkan mikrobia saprofit yang berperan mengurai bahan organik menjadi bahan yang lebih hancur, juga merusak bakal bibit yang akan tumbuh. Ada satu kondisi jika tanaman padi telah mengalami pemangkasan akan menghasilkan ukuran tanaman yang lebih pendek, maka kegiatan pemangkasan selanjutnya juga tidak meningkatkan tinggi tanaman, dan stabil ukuran tinggi sesuai dengan pangkasan 1 .

2. Berat Hijauan Makanan Ternak dan jerami padi MT1 dan ratun

Jerami tanaman padi yang dipanen saat matang fisiologi lebih tinggi pada MT2 dibandingkan pada MT2 (ratun), demikian pula HMT lebih tinggi pada MT1 dibandingkan MT2 (ratun) (Gambar 2). Hijauan makanan ternak (HMT) pada MT1 lebih tinggi 2 kali lipat dibandingkan HMT yang dihasilkan pada MT2. Hal ini

Demikian pula untuk hasil jerami yang dipanen saat matang fisiologis, terbukti juga tanaman padi yang mengalami panenan HMT akan menurunkan bobot jerami segarnya di lapangan. Dari fenomena ini membuktikan bahwa pemangkasan menurunkan HMT. Kemampuan tanaman padi melakukan pemulihan agak sulit jika tanaman sudah mengalami pemangkasan. Potensi menghasilkan hijauan kembali menjadi menurun setelah tanaman padi mengalami pemangkasan ratun.

terlihat bahwa hijauan yang diangkut pada saat awal primordial bunga sebagai HMT adalah kehilangan sejumlah jerami yang sama yang merupakan bagian dari penyusutan jerami yang dipanen saat fase 
matang fisiologis. Jika dijumlahkan antara HMT dipanen pada usia 45 hst dan berat jerami yang panen pada matang fisiologis merupakan jumlah akumulasi yang nilainya hampir sama dengan berat jerami tanpa dipanen HMTnya.

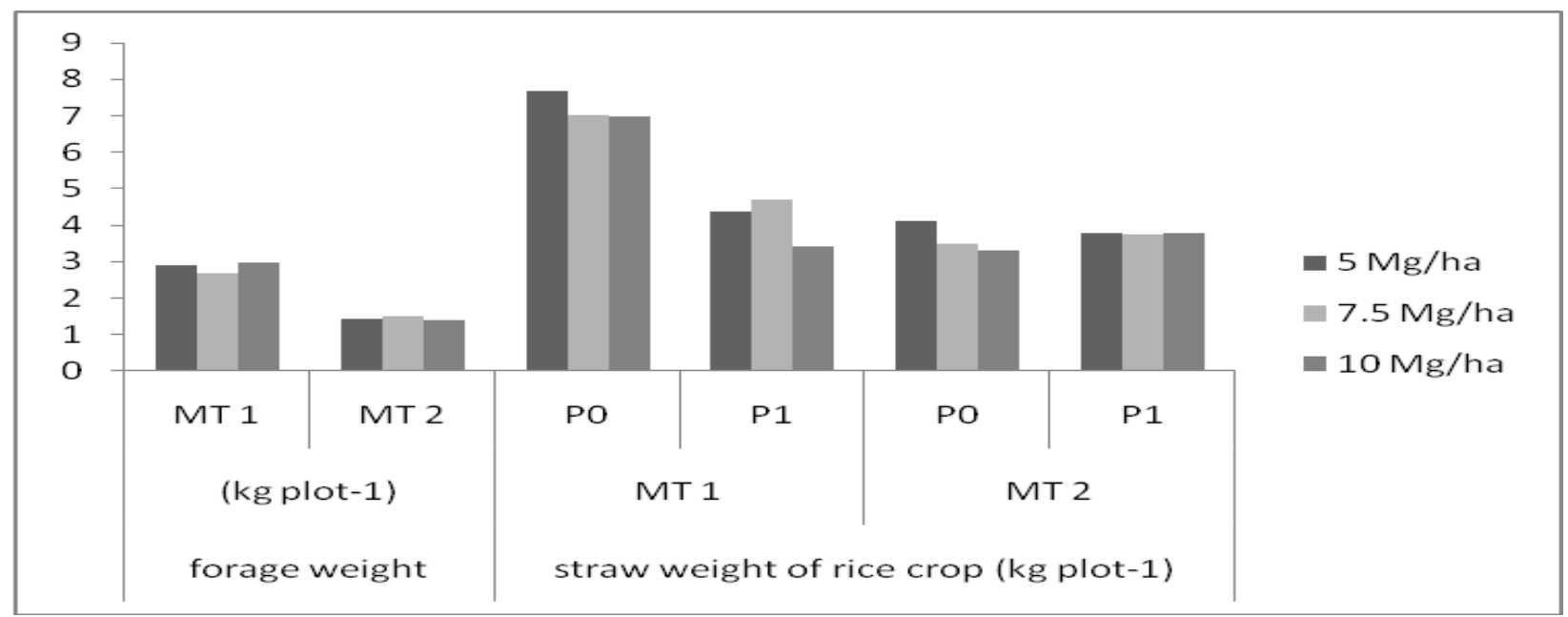

Gambar 2. Pengaruh Kompos C.odorata terhadap Berat Hijauan Makanan Ternak yang dipangkas saat awal primordial dan saat matang fisiologis

Keterangan: $\mathrm{P} 1=$ dipangkas; $\mathrm{P} 0=$ tidak dipangkas; MT1 = Musim tanam 1; MT 2= Musim tanam 2

Akan tetapi berbeda halnya dengan padi ratun (MT2), yang dipanen HMT nya, tidak menunjukkan fenomena tersebut. Hijauan Makanan Ternak yang dihasilkan pada MT2, menurun hampir 50\%, dibandingkan dengan HMT pada MT1. Jerami yang dihasilkan oleh tanaman padi MT2, baik yang dipangkas maupun yang tidak dipangkas, tidak ada perbedaan yang

\section{Umur berbunga dan panen tanaman padi}

Tanaman padi yang diratunkan (MT2) yang mendapat perlakuan yang tidak dipangkas, mengalami berbunga (75\%) lebih cepat dibandingkan dengan padi MT1, baik yang tidak dipangkas maupun yang dipangkas (Gambar 3). Demikian juga umur panen, lebih cepat pada tanaman padi MT2 yang tidak dipangkas. Secara umum pekerjaan ratun juga mempercepat usia panen tanaman nyata. Dari fenomena ini jelas terlihat, bahwa kemampuan tanaman padi untuk memulihkan brangkasan atas yang telah dipangkas baik pada MT1 maupun MT2, tidak seperti semula. Akan tetapi setelah MT2, dipangkas HMT maupun tidak, kemampuan sudah sama menghasilkan banyaknya jerami.

padi sekitar 10 hari. Selain itu usia tanaman juga dipersingkat karena tidak ada waktu yang terbuang dalam persemaian yang dilakukan 2 minggu, cukup hanya 1 minggu untuk persiapan bibit ratun. Jadi penghematan waktu berlangsung selama 17 hari. 


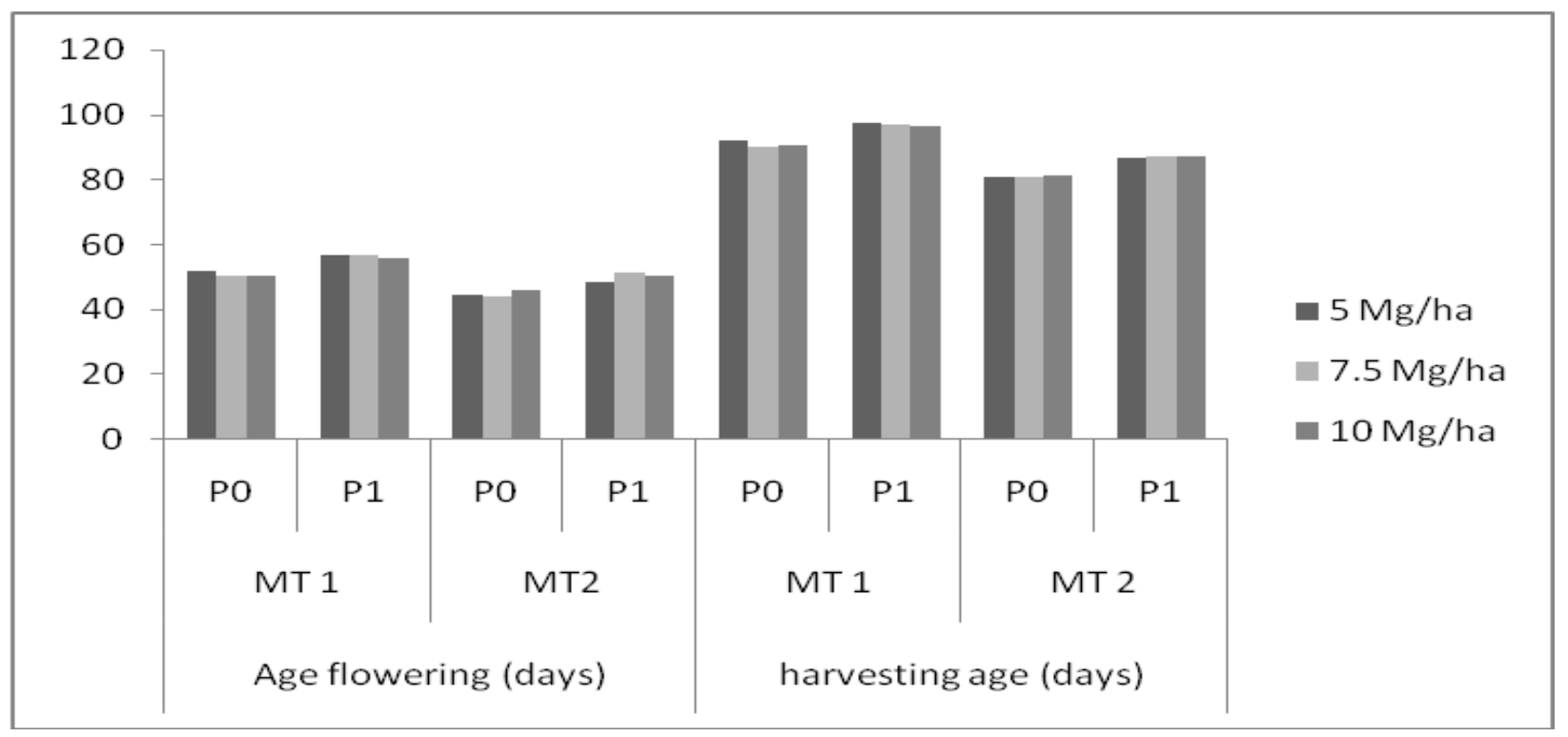

Gambar 3. Pengaruh Kompos C.odorata dan pemangkasan secara periodic terhadap Umur $75 \%$ berbunga dan panen (hst).

Keterangan: $\mathrm{P} 1=$ dipangkas; $\mathrm{P} 0=$ tidak dipangkas; $\mathrm{MT} 1=$ Musim tanam $1 ; \mathrm{MT} 2=$ Musim tanam 2

Pemanenan HMT saat primordial bunga, yang mengakibatkan keterlambatan usia panen pada MT1, dan kecenderungan setiap ada pemangkasan akan menjadi penundaan waktu panen baik pada MT1 maupun pada MT2. Umur panen setelah tanaman mencapai $75 \%$ pembungaan berlangsung lebih kurang 30 hari kemudian. Setiap ada pemotongan bagian vegetative tanaman padi, akan memperlambat usia berbunga maupun usia panen. Hal ini menunjukkan bahwa tanaman padi mengalami respon fisiologis yang jelas. Pemotongan bagian vegetative otomatis memperlambat tanaman memasuki fase 4. Pengaruh kompos C.odorata dan pemangkasan terhadap panjang malai dan bobot 1000 biji padi MT1 dan ratun (MT2).

Malai lebih panjang pada padi MT1 yang tidak dipangkas dibandingkan malai padi yang dipangkas HMT baik pada MT1 maupun pada ratun (MT2) (Gambar 4). Terbukti pengaruh pemangkasan tanaman generative, sehingga untuk memasuki fase generative tersebut, tanaman harus menyediakan energy dan mengumpulkan energinya dengan cukup. Hal ini dijelaskan oleh (Jamilah \& Juniarti, 2015) bahwa terjadi penundaan tanaman padi mulai berbunga ataupun memasuki fase matang fisiologis setelah tanaman mengalami pemangkasan. Hal ini disebabkan bagian vegetative tanaman padi yang diangkut atau dipanen memaksa tanaman untuk melakukan pemulihan sehingga akan menghasilkan perbanyakan atau pertumbuhan sel baru untuk memulihkan sel yang hilang. 
ukuran malai, walaupun tanaman padi sudah 3 kali mengalami pemangkasan yaitu 2 kali diambil HMT nya dan 1 kali pangkas ratun. Kestabilan ukuran panjang malai setelah mengalami pemanen HMT pada awal primordial bunga dan pada fase ratun (MT2) baik tidak dipanen HMTnya maupun yang dipanen menunjukkan pola yang sama bagi tanaman padi menghasilkan ukuran malai, akibat pengaruh pemotongan bagian vegetatifnya.

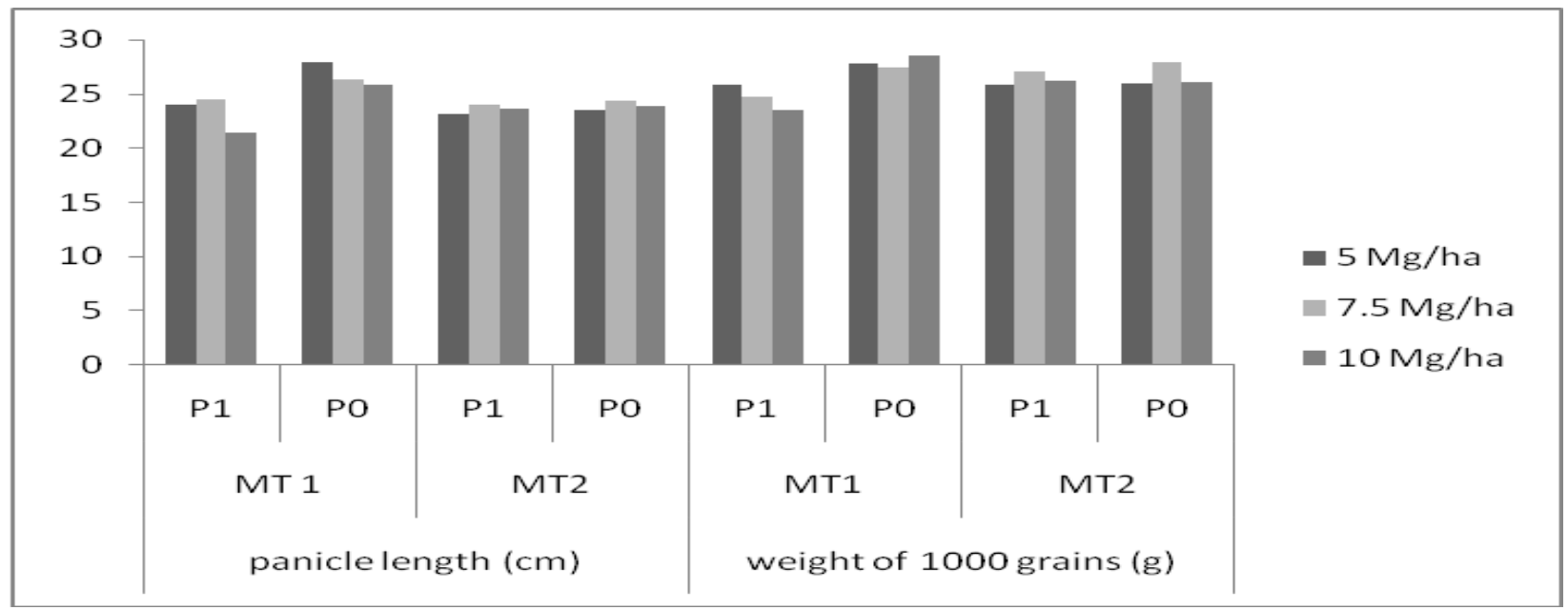

Gambar 4. Pengaruh Kompos C.odorata dan pemangkasan secara periodic terhadap Panjang malai dan bobot 1000 butir gabah

Keterangan: $\mathrm{P} 1=$ dipangkas; $\mathrm{P} 0=$ tidak dipangkas; $\mathrm{MT} 1=$ Musim tanam $1 ;$ MT $2=$ Musim tanam 2

Bobot 1000 biji gabah padi ternyata tidak dipengaruhi oleh pemangkasan secara periodic tanaman padi. Berarti tidak ada pengaruh pemangkasan hingga beberapa kali dalam menurunkan ukuran gabah, serta kandungan gabah. Hal ini telah dibuktikan bahwa ukuran dan kandungan pati hampir sama baik yang dipangkas HMT nya maupun tidak pada MT1 dan MT2. Secara umum pengaruh pemupukan tidak berbeda antara komposisi perlakuan B1, B2 dan B3 terhadap panjang malai maupun bobot 1000 biji gabah padi. Hal ini disebabkan karena tanaman padi mendapatkan unsur hara yang cukup baik dari B1, B2 maupun B3.

5. Pengaruh Kompos C.odorata dan pemangkasan secara periodic terhadap hasil gabah kering panen

Berat gabah kering panen sangat ditentukan oleh pemangkasan pada MT1, dan tidak berpengaruh nyata dari pemberian kompos C.odorata disajikan pada Gambar 5. 


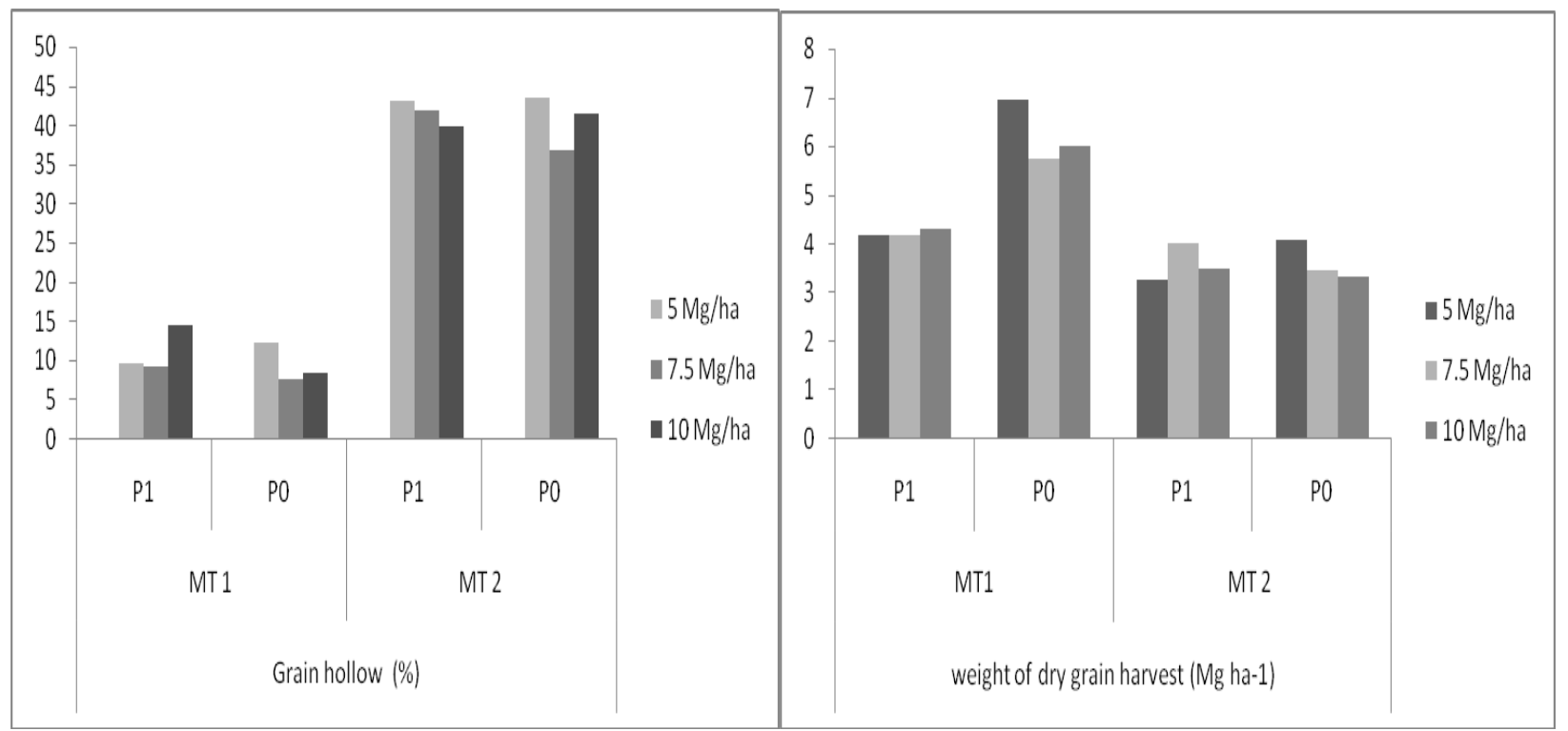

Gambar 5. Pengaruh Kompos C.odorata dan pemangkasan secara periodic terhadap hasil gabah kering panen

Keterangan: P1= dipangkas; P0= tidak dipangkas; MT1 = Musim tanam 1; MT 2= Musim

tanam 2

Hasil gabah kering panen diperoleh pada MT1 tertinggi mencapai rerata 5,40 $\mathrm{Mg}^{-}$ 1, dan 3,62 $\mathrm{Mg} \mathrm{ha}^{-1}$ pada MT2 (ratun) dengan total gabah kering giling (GKG) sebanyak $9,02 \mathrm{Mg} \mathrm{ha}^{-1}$ pada perlakuan yang tidak dipangkas HMTnya. Jika tanaman

Jika harga gabah kering giling $1 \mathrm{~kg}$ ditingkat petani adalah Rp. 6000,- dan 25 kg HMT seharga Rp. 10.000,-, maka tanaman padi yang tidak dipangkas hingga diratunkan mencapai penghasilan sebesar 9,02 x 1000 x Rp. 6000,-= 54.120.000,Sedangkan yang dipangkas HMTnya mendapatkan penghasilan= 7,82 x $1000 \mathrm{x}$ Rp 6000,-= 46.920.000,- dari GKG. Total penghasilan dari hijauan yang dipangkas dipangkas HMTnya, maka hasil gabah pada MT1 diperoleh hanya $4,22 \mathrm{Mg} \mathrm{ha}^{-1}$ pada panen MT1, dan 3,60 $\mathrm{Mg} \mathrm{ha}^{-1}$ pada MT2(ratun), dengan total GKG mencapai $7,82 \mathrm{Mg} \mathrm{ha}^{-1}$ dan mendapatkan tambahan sebanyak $10,75 \mathrm{Mg} \mathrm{ha}^{-1}$.

sebesar $=10,75 \times 1000 \times 10.000 / 25=$ Rp.4.300.000,-, dengan total Gabah + HMT sebanyak Rp. 51.220.000,- Ada selisih penghasilan antara padi yang tidak dipanen HMTnya dengan tanaman padi yang mengalami pemanen HMT sebanyak Rp. 2.900.000,- (dua juta Sembilan ratus ribu rupiah).

\section{SIMPULAN}

Tidak ada pengaruh yang berbeda antara komposisi pemberian kompos C.odorata + pupuk buatan, terhadap pertumbuhan dan hasil padi baik pada MT1 maupun pada MT2 (ratun). Hijauan makanan ternak (HMT) menurun perolehannya pada MT2 
(ratun) hingga 50\% dibandingkan HMT MT1. Terjadi peningkatan gabah hampa hingga 4 kali lipat pada sistem ratun (MT2) dibandingkan MT1. Dari segi ekonomi, ada

\section{UCAPAN TERIMA KASIH}

Ucapan terima kasih disampaikan kepada Kemenristek Dikti melalui Koordinator Kopertis $\mathrm{x}$ yang telah mendanai sebagaian kegiatan penelitian ini melalui skim penelitian Stranas tahun Anggaran 2015, Nomor: 262/MPK.A4/KP2014; DIPA Dirjen Dikti Tahun 2015 No SP DIPA023.04.1.673453/2015, tanggal 14 November

\section{DAFTAR PUSTAKA}

Badan Pengawas Perdagangan Berjangka Komoditi 2016. Harga Komoditi Ditingkat Petani. http://infoharga.bappebti.go.id/harga_k omoditi_petani

Dr. Kim H. Tan. (2013). Humo-Nanotube Membrane Relation With Biopolymers. In Journal of Chemical Information and Modeling (Vol. 53, pp. 16891699). Department of Crops and Soil Science The University of Georgia, Athens, GA, USA PREFACE. http://doi.org/10.1017/CBO978110741 5324.004

Jamilah. (2010). Serapan hara dan hasil Jagung yang Diaplikasi Pupuk Buatan dan KOmpos Kronobio. Agrivigor, 10 (1), 10-17.

Jamilah. (2011). Pengaruh Jenis dan Takaran Kompos C.odorata dan Guano Untuk Pertumbuhan dan Hasil Jagung pada Typic Paleudult. Jurnal Imiah Ekotrans, 11 No. 2, 71-78. http://doi.org/10.1017/CBO978110741 5324.004

Jamilah, Adrinal, Khatib, I., \& Nusyirwan. (2011). Reklamasi Tanah yang Kena Dampak Limbah Bahan Baku Tambang Semen Melalui Pemanfaatan Pupuk Organik In Situ Untuk Meningkatkan kerugian petani, melakukan pemangkasan, hingga MT2, sebesar Rp. 2,9 juta rupiah dibandingkan tanaman yang tidak dipangkas akan tetapi juga diratunkan.

2014, Dengan Surat Perjanjian Penugasan Dalam Rangka Pelaksanaan Program Penelitian No. 10/KONTRAK/010/KM/2015, tanggal 16 Februari 2015. Ucapan terima kasih juga disampaikan kepada Bapak Rektor Universitas Tamansiswa Padang yang telah memfasilitasi dan memberikan perhatian dan saran.

Hasil Padi Sawah. In Seminar Nasional dengan topik Pengembangan Pertanian Terpadu Berbasis Organik Menuju Pembangunan pertanian Berkelanjutan (pp. 172-189).

Jamilah, \& Helmawati. (2015). Kajian Analisis Usaha Tani Integrasi Padi Sawah dan Pakan Ternak Ruminansia Menunjang Kedaulatan Pangan dan Daging Dalam Menghadapi Masyarakat Ekonomi Asean 2015. In Seminar Nasional Kesiapan Indonesia dalam Menghadapi Pasar Bebas Asean Melalui Penguatan Implementasi Corporate Governance yang Sehat (Vol. 3, pp. 254-266). Padang: Perpustakaan Nasional RI.

Jamilah, \& Juniarti. (2015). Potensi Tanaman Padi Dipangkas Secara Periodikuntuk Pakan Ternak Pada Metoda Budidaya Integrasi Padi Ternak Menunjang Kedaulatan Pangan Dan Daging. :Laporan Penelitian Fakultas Pertanian Univ. Tamansiswa, Padang (Vol. 53). Padang.

Jamilah, Juniarti, \& Mulyani, S. (2016). Potensi tanaman padi yang dipupuk dengan kompos $\mathrm{C}$ hromolaena odorata; penghasil gabah dan sumber hijauan pakan ternak penunjang ketahanan 
pangan Potential of rice crop fertilized with compost of Chromolaena odorata to produce grain yield and. Prosiding Sem.Nas.Masy.Biodiv.Indon, 2, 27-31. http://doi.org/10.13057/psnmbi/m0201 05

Jamilah, Novia, P., Suardi, \& Renor, Y. (2010). Peranan Kompos Krono Mengganttkan Pupuk Buatan Untuk Meningkatkan \}Iasil Jagling Pada Allwial Bandar Buatpadang (Tahap 2) Jamilah*. Bulletin Ilmiah Ekasakti, Xix, 2-5.

Larney, F. J., Henry Janzen, H., \& Olson, A. F. (2011). Residual effects of one-time manure, crop residue and fertilizer amendments on a desurfaced soil. Canadian Journal of Soil Science, 91(6), 1029-1043. http://doi.org/10.4141/cjss 10065

Maswar, M., \& Soelaeman, Y. (2016). Effects of Organic and Chemical Fertilizer Inputs on Biomass Production and Carbon Dynamics in a Maize Farming on Ultisols. AGRIVITA Journal of Agricultural Science, 38(2), 133-141.

http://doi.org/10.17503/agrivita.v38i2.5 94

Mengel, K., Kirkby, E. a., Kosegarten, H., \& Appel, T. (2001). Principles of Plant Nutrition Edited by and, 5th, $849 \mathrm{pp}$. http://doi.org/10.1007/978-94-0101009-2 